\title{
Proportion of Testicular Absence and Position of Testis in Unilateral Nonpalpable Undescended Testis in a Tertiary Teaching Hospital in South India
}

\author{
Aravind C S', Sam Varkey ${ }^{1}$,Shinaz Sadiq², Binu M K², Prathibha Sukumar ${ }^{3}$ \\ ${ }^{1}$ Associate Professor, Department of Paediatric Surgery, Government Medical College Trivandrum, Kerala, \\ India. \\ ${ }^{2}$ Assistant Professor, Department of Paediatric Surgery, Government Medical College Trivandrum, Kerala, India \\ ${ }^{3}$ Senior Resident, Department of Paediatric Surgery, Government Medical College Trivandrum, Kerala, India
}

Corresponding Author: Aravind C S

DOI: https://doi.org/10.52403/gijhsr.20220101

\begin{abstract}
Introduction: Undescended testis is a common surgical problem in children which needs to be treated by one and a half year of age. When testis is non palpable, it could be either absent, and when present intra-abdominal or inguinal.

Methodology: A hospital based retrospective study was conducted in department of paediatric surgery, Thiruvananthapuram. Study population consisted of children treated with nonpalpable undescended testis from January 2016 to June 2021.
\end{abstract}

Results: Mean age of intervention was 43.7 months (range 7 to 153 months). Incidence of absent testis was $30.97 \%$. in 156 children who had ipsilateral undescended testis, 92 had intraabdominal testis and 43 had inguinal testis. Presence of nubbin of testis in ipsilateral scrotum and contralateral testicular hypertrophy were suggestive of absent ipsilateral testis ( $p$ $<0.001$ ). Testis is absent in $11.3 \%$ only when ipsilateral hemi scrotum is under developed.

Conclusion: Proportion of absent testis is $30.97 \%$ in children with unilateral undescended testis. Presence of nubbin of testis in ipsilateral scrotum and contralateral testicular hypertrophy are predictive of ipsilateral testicular absence.

Key Words: Undescended testis, atrophic testis, Contralateral hypertrophy

\section{INTRODUCTION}

Cryptorchidism or an undescended testis (UDT) is one of the common genital anomaly in boys. The definition of cryptorchidism is that a testicle is not within the scrotum and cannot be manipulated into the scrotum. The incidence of cryptorchidism is approximately $2 \%$ (0.7$2.8 \%$ ) in new-borns, and $1 \%$ in 1 -year-olds; $80 \%$ of these undescended testes are clinically palpable and $20 \%$ of them are nonpalpable ${ }^{[1-3]}$

Children presenting with unilateral nonpalpable undescended testis may be having anorchia (absent testis)/atrophic testis or, intra-abdominal testis or inguinal testis. Standard treatment for non-palpable testis is laparoscopy which helps to identify the presence/ absence of testis and its position when present. The children with undescended testis - nonpalpable [UDT(NP)], $23 \%$ children have intraabdominal testis while in $60-64 \%$ testis is absent ${ }^{[2,3]}$. In rest of children testis is in inguinal canal. Nubbin in scrotum and contralateral testicular hypertrophy is said to be a marker of ipsilateral absence of testis. Operative findings suggestive of absent testis are blind ending vessels and a closed deep ring or nubbin of tissue at the tip of vas $\&$ vessels (atrophic testis)

Timing of surgical correction in children with undescended testis is 6 months to 12 months of age ${ }^{[4-8]}$. Many of our children are presenting late and hence undergo treatment much later which may affect the outcome. In the present study an 
attempt is made to find the proportion of ipsilateral testicular absence and position of testis in children presenting with unilateral nonpalpable undescended testis in a tertiary care teaching hospital in South India.

\section{MATERIALS AND METHODS}

This is a retrospective observational study conducted in department of paediatric surgery, SAT Hospital, Government Medical college, Thiruvananthapuram. Records of children who underwent treatment for nonpalpable unilateral undescended testis from January 2016 to June 2021 were retrieved and data collected. Those with bilateral undescended testis were excluded from the study.

All children with nonpalpable testis underwent laparoscopy as standard treatment. Laparoscopy was used to ascertain position of testis and to treat intraabdominal testis. Absent testis/ vanishing testis was diagnosed by blind ending vas and vessels at or proximal to deep ring. Presence of hernia along with vas and vessel entering inguinal canal suggest inguinal testis and inguinal exploration was done. Closed ring with vas and vessels entering the deep ring suggest testicular atrophy/ vanishing testis and was confirmed by inguinal exploration. The testis identified in intra-abdominal position was treated with single stage or two stage orchiopexy depending on length of vessel as suggested by mobility and position of testis. The position testis was classified as intraabdominal, at deep inguinal ring, peeping testis (testis inside inguinal canal which enter abdominal cavity intermittently) and inguinal testis

The following data were retrieved from the records - age of presentation, clinical findings (presence of nubbin, development of scrotum), findings in laparoscopy (presence/ absence of testis, position of testis if present and any associated anomalies. These data were entered in Microsoft excel sheet. Analysis was done using open-source statistical software 'jamovi 2 ' ${ }^{[9,10]}$.

\section{RESULTS}

During the study period from January 2016 to June 2021, 267 children underwent treatment for nonpalpable undescended testis, 41 were bilateral and were excluded from the study. Data of 226 children were collected and analysed.

Age of intervention varied from 7 months to 153 months (12yr 9 months) with a mean age of 43.7 months and median age of 29 months. Of 226, $136(60.18 \%)$ had left sided undescended testis and 90 (39.82\%) right sided.

The pattern of age at intervention/ presentation is given below

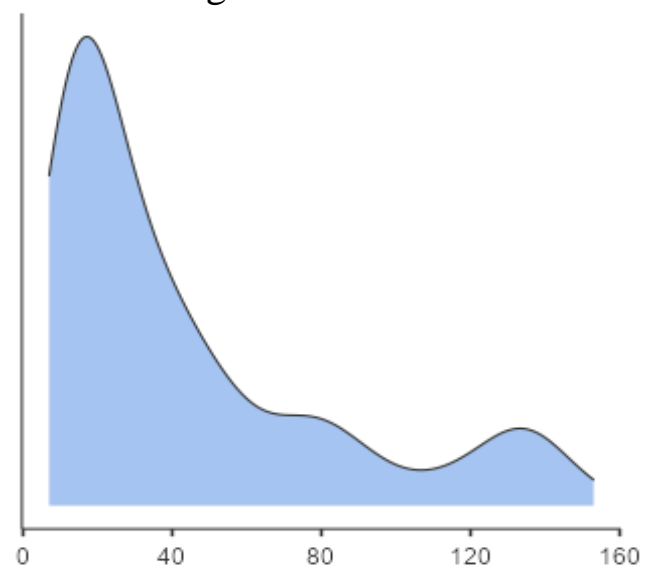

Figure 1. Age distribution, $X$ axis age in months

Analysis of clinical findings showed underdeveloped scrotum in 91 (40.3\%), nubbin of tissue present in $19(8.4 \%)$ and 207 (91.6\%) had empty scrotum. 53 (23.6\%) children had hypertrophy of contralateral testis.

Following table show the associated anomalies seen in these children. 23 children had associated anomalies. Commonest anomaly identified was contralateral inguinal hernia in $13(5.75 \%)$ children followed by hypospadias in 4 $(1.77 \%)$.

Table 1 Associated anomalies in Unilateral nonpalpable undescended testis

\begin{tabular}{|l|l|l|}
\hline Anorectal malformation & 1 & $0.4 \%$ \\
\hline Hirschsprung's disease & 1 & $0.44 \%$ \\
\hline Hypospadias & 4 & $1.77 \%$ \\
\hline Crossed fused ectopia - kidney & 1 & $0.44 \%$ \\
\hline Renal Agenesis- Ipsilateral & 1 & $0.44 \%$ \\
\hline Inguinal Hernia- contralateral & 13 & $5.75 \%$ \\
\hline Posterior urethral Valve & 1 & $0.44 \%$ \\
\hline Trisomy 21 & 2 & $0.88 \%$ \\
\hline Wilms Tumour & 2 & $0.88 \%$ \\
\hline
\end{tabular}


Aravind C S et.al. Proportion of testicular absence and position of testis in unilateral nonpalpable undescended testis in a tertiary teaching hospital in South India.

Of the 226 children, $156(69.03 \%)$ had testis in inguinal region or inside abdomen, in rest $70(30.97 \%)$ children the ipsilateral testis was absent- either atrophic or vanishing testis. In 70 children with absent ipsilateral testis, 44 had vanishing testis (blind ending vas \& vessels) and 26 had atrophic testis. In 44 children with vanishing testis, 16 had blind ending vas at or proximal to deep inguinal ring.

156 children who had the ipsilateral undescended testis present had distribution of testicular position as shown in the table 2 .

Table 2. Position of testis in those who had ipsilateral testis

\begin{tabular}{|l|l|l|}
\hline Position of testis & Count & Proportion \\
\hline Ant ab wall & 1 & 0.00641 \\
\hline Deep Ring & 13 & 0.08333 \\
\hline Inguinal & 43 & 0.27564 \\
\hline Intra ab & 92 & 0.58974 \\
\hline Peeping & 7 & 0.04487 \\
\hline
\end{tabular}

The commonest position of testis was intra-abdominal, $92(59.4 \%)$, of these 52 were within an inch from deep inguinal ring and 40 were more than 1 inch proximal to deep inguinal ring.

The relation between presence of nubbin of tissue in scrotum to absence of ipsilateral testis is shown in Table 3. In those having empty hemi scrotum 156 $(75.36 \%)$ had ipsilateral testis, while none of those having nubbin of tissue in scrotum had testis on that side. The results were statistically significant $(\mathrm{p}<0.001)$.

Table 3 Relation of ipsilateral testicular absence and presence of nubbin of tissue in scrotum

\begin{tabular}{|l|l|l|l|}
\hline & Absent & Present & Total \\
\hline Empty hemi-scrotum & 51 & 156 & 207 \\
\hline Nubbin in scrotum & 19 & 0 & 19 \\
\hline Total & 70 & 156 & 226 \\
\hline
\end{tabular}

Similarly, the relation between presence of hypertrophy of contralateral testis to absence of ipsilateral testis shown in Table 4. All children with contralateral testicular hypertrophy had absent ipsilateral testis while $156(90.17 \%)$ of those who didn't have contralateral testicular hypertrophy had ipsilateral testis in abdomen or inguinal canal. The results were statistically significant $(\mathrm{p}<0.001)$
Table 4 Relation of contralateral testicular hypertrophy and ipsilateral testicular absence

\begin{tabular}{|l|l|l|l|}
\hline & \multicolumn{2}{l|}{$\begin{array}{l}\text { Contralateral testicular } \\
\text { hypertrophy }\end{array}$} & \\
\hline & Absent & Present & Total \\
\hline Absent ipsilateral testis & 17 & 53 & 70 \\
\hline Present ipsilateral testis & 156 & 0 & 156 \\
\hline Total & 173 & 53 & 226 \\
\hline
\end{tabular}

Relation between development of ipsilateral hemi-scrotum to presence or absence of ipsilateral testis was also analysed and shown in table 5. In 135 with normally developed hemi-scrotum, $62(45.93 \%)$ had ipsilateral absent testis while $73(54.07 \%)$ had presence of ipsilateral testis while $83(91.21 \%)$ out of 91 with underdeveloped scrotum had testis in inguinal or intra-abdominal position. This finding was also statistically significant ( $p$ $<0.001$ )

Table 5 Relation of ipsilateral hemi-scrotal development and presence of ipsilateral testis

\begin{tabular}{|l|l|l|l|}
\hline & \multicolumn{2}{|l|}{$\begin{array}{l}\text { Development of Hemi- } \\
\text { scrotum }\end{array}$} & \\
\hline & Normal & Underdeveloped & Total \\
\hline Ipsilateral testis Absent & 62 & 8 & 70 \\
\hline Ipsilateral testis Present & 73 & 83 & 156 \\
\hline Total & 135 & 91 & 226 \\
\hline
\end{tabular}

\section{DISCUSSION}

Undescended testis is a common urological anomaly with an incidence of around $1-2 \%$ of male babies at 6 months of age. ${ }^{[11,12]}$ Completion of treatment of undescended testis (by orchiopexy) is recommended within 18 months of age and laparoscopy is recommended for nonpalpable undescended testis. ${ }^{[13,14]}$

Age of treatment in this study ranged from 7 months to 153 months with a mean age of 43.7 months and median age of 29 months. It was higher than the recommended age, it is because of delayed presentation/ reference to our institution. Snodgrass $\mathrm{W}$ et al ${ }^{[2]}$ reports a similar mean age of presentation (43.3months). Zlatan Zvizdic et al ${ }^{[11]}$ and Hori $S$ et al ${ }^{[15]}$ reports a mean age of 24 months. Bergbrant $S$ et al [12] reports decrease in median age of treatment from $6.2 \mathrm{yrs}$ in 2001 to $3.4 \mathrm{yrs}$ in 2014. In our study $136(60.18 \%)$ had left sided undescended testis and $90(39.82 \%)$ right sided. Hori $\mathrm{S}$ et al ${ }^{[15]}$ also reports a similar predominance on left side. 
In this study the commonest associated anomaly is contralateral inguinal hernia $(5.75 \%)$ followed by hypospadias $(1.77 \%)$. Study by Hori $\mathrm{S}$ et al shows the incidence of $5 \%$ for inguinal hernia and $7 \%$ hypospadias. Incidence of hypospadias was lower in our study.

This study has $30.97 \%$ incidence of unilateral absent testis either vanishing testis or atrophic testis. Others report higher incidence of absent testis as follows, $41 \%$ reported by Kirsch AJ et al ${ }^{[16]}, 62.14 \%$ by Guiney E.J et al ${ }^{[17]}$ and $51.85 \%$ by Gulanikar A et al. Ipsilateral testis was present 156 children in this study, of these $92(58.97 \%)$ was intra-abdominal and 43 $(27.56 \%)$ were inguinal in position. Kirsch AJ et al ${ }^{[16]}$ report that 91 out of 266 testis present in their study was intra-abdominal, which is less than the proportion in our study.

When there was nubbin (possible atrophic testicular remanent) in ipsilateral scrotum ipsilateral testis was absent (19/19) while 156 out of 207 children with empty scrotum had ipsilateral testis. It was statistically significant also $(\mathrm{p}<0.001)$. Belman et al ${ }^{[18]}$ also reports similar finding and they suggest diagnostic laparoscopy is not required if nubbin is found in scrotum. Presence of nubbin suggest ipsilateral absent testis.

Similarly, presence of contralateral testicular hypertrophy also had statistically significant relation with ipsilateral absence of testis. When contralateral hypertrophy of testis was present in 53 children with nonpalpable UDT, none of them had ipsilateral testis ( $p<0.001)$. Hurwitz RS et al [19] found that contralateral testicular hypertrophy of $18 \mathrm{~mm}$ is predictive of absent ipsilateral testis with accuracy of 90 and Braga L.H et al ${ }^{[20]}$ found $95 \%$ CI: 91$100 \%$.

Another finding in our study is the relation between development of ipsilateral hemi-scrotum and presence or absence of ipsilateral testis, which was statistically significant $(\mathrm{p}<0.001)$. When the ipsilateral hemi-scrotum is poorly developed the chance of ipsilateral testis being absent is low $(11.43 \%)$. But we couldn't find any article to compare our results.

\section{CONCLUSION}

Late presentation/ referral of undescended testis is still high with mean age of 43.7 months, even though the treatment should be ideally completed by 18 months of age. Proportion of absent testis is $30.97 \%$ in children with unilateral nonpalpable undescended testis. Presence of nubbin of testis in ipsilateral scrotum and contralateral testicular hypertrophy are predictive of ipsilateral testicular absence.

156 children had ipsilateral testis, among them $92(58.97 \%)$ was intraabdominal, $43(27.56 \%)$ were inguinal in position, 13 at deep ring, 7 were peeping testis and one was found in anterior abdominal wall.

Acknowledgement: None

\section{Conflict of Interest: Nil}

\section{Source of Funding: Nil}

Ethical Approval: Institutional research committee clearance and Institutional Ethical committee clearance obtained for the study

\section{REFERENCES}

1. Hueih-ShingHsu, Management of boys with nonpalpable undescended testes, Urological Science, Volume 23, Issue 4, December 2012, 103-106

2. Snodgrass W, Bush N, Holzer M, Zhang S. Current referral patterns and means to improve accuracy in diagnosis of undescended testis. Pediatrics. 2011; 127(2):e382-e388. doi:10.1542/peds.2010-1719

3. Sepúlveda $X$, Egaña PL. Current management of non-palpable testes: a literature review and clinical results. Transl Pediatr. 2016;5(4):233-239. doi:10.21037/tp.2016.10.06 
4. Docimo SG, Silver RI, Cromie W. The undescended testicle: diagnosis and management. Am Fam Physician. 2000 Nov 1;62(9):2037-44, 2047-8. PMID: 11087186.

5. Fratrić I, Šarac D, Antić J, Đermanov M, Jokić R. Impalpable Testis: Evaluation of Diagnostic and Treatment Procedures and Our Treatment Protocol. Biomed Res Int. 2018 Jul 17; 2018:3143412. doi: 10.1155/2018/3143412. Erratum in: Biomed Res Int. 2021 Jan 28; 2021:6890257. PMID: 30112376; PMCID: PMC6077678

6. John M Huston, Jorgen M Thorup, Spencer W Beasley (editors): Desend of the Testis $2^{\text {nd }}$ ed,2016

7. Thomas F Kolon, Gregory E Tasian:Cryptorchidism, The Kelalis King- Belman Textbook of Clinical Pediatric Urology, $6^{\text {th }}$ ed $1345-1358$

8. Julia Spencer Barthold, Jennifer A. Hagerty: Etiology, Diagnosis, and Management of the Undescended Testis, Campbell-Walsh-Wein Urology $12^{\text {th }}$ ed 949- 972

9. The jamovi project (2021). jamovi. (Version 1.8) [Computer Software]. Retrieved from https://www.jamovi.org.

10. $\mathrm{R}$ Core Team (2021). R: A Language and environment for statistical computing. (Version 4.0) [Computer software]. Retrieved from https://cran.rproject.org. (R packages retrieved from MRAN snapshot 2021-04-01).

11. Zlatan Zvizdic, Belma Islamovic, Emir Milisic, Asmir Jonuzi, Semir Vranic; Changing Trends in the Referral and Timing of Treatment for Congenital Cryptorchidism: A Single-Center Experience from Bosnia and Herzegovina; Journal of Pediatric Surgery, Vol55, issue9,P19651968,September 2020 https://doi.org/10.1016/j.jpedsurg.2019. 08.013

12. Bergbrant S, Omling E, Björk J, Hagander L. Cryptorchidism in Sweden: A Nationwide Study of Prevalence,
Operative Management, and Complications. J Pediatr. 2018 Mar; 194:197-203.e6.

doi: 10.1016/j.jpeds.2017.09.062. Epub 2018 Jan 10. PMID: 29331326.

13. Radmayr C, Dogan HS, Hoebeke P, Kocvara R, Nijman R, Silay S, Stein R, Undre S, Tekgul S. Management of undescended testes: European Association of Urology/European Society for Paediatric Urology Guidelines. J Pediatr Urol. 2016 Dec;12(6):335-343. doi: 10.1016/j.jpurol.2016.07.014. Epub 2016 Sep 15. Erratum in: J Pediatr Urol. 2017 Apr;13(2):239. PMID: 27687532.

14. Kolon TF, Herndon CD, Baker LA, Baskin LS, Baxter CG, Cheng EY, Diaz M, Lee PA, Seashore CJ, Tasian GE, Barthold JS; American Urological Assocation. Evaluation and treatment of cryptorchidism: AUA guideline. J Urol. 2014 Aug;192(2):337-45. doi: 10.1016/j.juro.2014.05.005. Epub 2014 May 20. PMID: 24857650.

15. Hori S, Aoki K, Nishimura N, Morizawa Y, Gotoh D, Fukui S, Nakai Y, Miyake M, Torimoto K, Fujimoto K. Trends in the Treatment Outcomes and Features of Cryptorchidism in Boys: A SingleInstitute Experience. Res Rep Urol. 2020;12:373-381 https://doi.org/10.2147/RRU.S271869

16. Kirsch AJ, Escala J, Duckett JW, Smith GH, Zderic SA, Canning DA, Snyder HM 3rd. Surgical management of the nonpalpable testis: the Children's Hospital of Philadelphia experience. J Urol. 1998 Apr;159(4):1340-3. PMID: 9507881.

17. Guiney E.J., Corbally M. and Malone P.S. (1989), Laparoscopy and the Management of the Impalpable Testis. British Journal of Urology, 63: 313316. https://doi.org/10.1111/j.1464410X.1989.tb05196.x

18. Belman, A. and Rushton, H. (2001), Is the vanished testis always a scrotal event? BJU International, 87: 480- 
Aravind C S et.al. Proportion of testicular absence and position of testis in unilateral nonpalpable undescended testis in a tertiary teaching hospital in South India.

483. https://doi.org/10.1046/j.1464410X.2001.00101.X

19. Hurwitz RS, Kaptein JS. How well does contralateral testis hypertrophy predict the absence of the nonpalpable testis? J Urol. 2001 Feb;165(2):588-92. doi: 10.1097/00005392-200102000-00077. PMID: 11176443.

20. Braga L.H., Kim S., Farrokhyar F., Lorenzo A.J. Is there an optimal contralateral testicular cut-off size that predicts monorchism in boys with nonpalpable testicles? Journal of Pediatric Urology, (2014) 10 (4), pp. 693-698.

How to cite this article: Aravind CS, Sam Varkey, Shinaz Sadiq et.al. Proportion of testicular absence and position of testis in unilateral nonpalpable undescended testis in a tertiary teaching hospital in South India. Gal Int J Health Sci Res. 2022; 7(1): 1-6. DOI: https://doi.org/10.52403/gijhsr.20220101 